\title{
Desenvolvimento da leitura na educação infantil: o papel da ludicidade
}

\author{
Reading development in early childhood education: the role of playfulness \\ Desarrollo de la lectura en la educación infantil: el papel de la alegría
}

Recebido: 29/12/2021 | Revisado: 07/01/2022 |Aceito: 11/01/2022| Publicado: 13/01/2022

\author{
Adriana Maria de Melo Rodrigues \\ ORCID: https://orcid.org/0000-0003-0408-1621 \\ Universidade Paulista, Brasil \\ E-mail: adriamelorodrigues@gmail.com \\ Elizabeth Gomes da Rocha Cordeiro \\ ORCID: https://orcid.org/0000-0002-0906-5842 \\ Universidade Paulista, Brasil \\ E-mail: bethecarlos@outlook.com \\ Keila Noeme da Penha Moreira \\ ORCID: https://orcid.org/0000-0002-8098-3849 \\ Universidade Paulista, Brasil \\ E-mail:kndpm20@gmail.com \\ Natália da Silva Pereira \\ ORCID: https://orcid.org/0000-0003-4090-922X \\ Universidade Paulista, Brasil \\ E-mail: natalia.silva.pereira1995@gmail.com \\ Taís Renata de França Cruz \\ ORCID: https://orcid.org/0000-0001-6936-6703 \\ Universidade Paulista, Brasil \\ E-mail: taisrenatadefrancacruz@hotmail.com \\ José Eduardo Silva \\ ORCID: https://orcid.org/0000-0002-8483-0305 \\ Universidade Paulista, Brasil \\ E-mail: silva.j.e@ outlook.com
}

\section{Resumo}

A pesquisa tem por objetivo refletir e compreender a importância da ludicidade na aquisição da leitura, bem como apresentar meios lúdicos do tipo: literatura, jogos infantis e o brincar, expressões artísticas e práticas musicais. Como instrumentos de aprendizagem nos anos iniciais, descrevendo os benefícios que cada atividade pode proporcionar para os alunos da educação infantil. Discorre-se sobre como o professor pode utilizar os recursos lúdicos em suas práticas pedagógicas, considerando que cada um contribui significativamente para a promoção da aprendizagem efetiva e também para a alfabetização. $\mathrm{O}$ foco da pesquisa está na perspectiva sociointeracionista, presente nas experiências que a criança vive por meio das interações com o meio, com outras crianças, com os adultos e consigo mesma. $\mathrm{O}$ estudo teve como procedimento metodológico a pesquisa bibliográfica, através da revisão de literatura em fontes de informação como livros, artigos científicos e trabalhos acadêmicos. Pode-se considerar que buscou-se reiterar a importância da ludicidade e dos instrumentos pedagógicos como aliados ao processo de desenvolvimento da leitura no contexto escolar, objetivando oferecer propostas para a viabilização de uma prática pedagógica prazerosa, formativa e saudável para as crianças, através da ludicidade e das múltiplas linguagens infantis.

Palavras-chave: Ensino infantil; Letramento; Instrumentos de aprendizagem; Ludicidade.

\begin{abstract}
The research aims to reflect and understand the importance of playfulness in the acquisition of reading, as well as presenting playful media such as: literature, children's games and playing, artistic expressions and musical practices. As learning tools in the early years, describing the benefits that each activity can provide for early childhood education students. It discusses how the teacher can use recreational resources in their pedagogical practices, considering that each one contributes significantly to the promotion of effective learning and literacy. The focus of the research is on the socio-interactionist perspective, present in the experiences that children live through interactions with the environment, with other children, with adults and with themselves. The study had as methodological procedure the bibliographical research, through literature review in information sources such as books, scientific articles and academic works. It can be considered that an attempt was made to reiterate the importance of playfulness and pedagogical instruments as allies to the process of developing reading in the school context, aiming to offer proposals for the feasibility of a pleasant, formative and healthy pedagogical practice for children, through playfulness and multiple children's languages.
\end{abstract}

Keywords: Kindergarten; Literacy; Learning instruments; Playfulness. 


\begin{abstract}
Resumen
La investigación tiene como objetivo reflexionar y comprender la importancia de la alegría en la adquisición de la lectura, así como presentar medios lúdicos como: literatura, juegos y juegos infantiles, expresiones artísticas y prácticas musicales. Como herramientas de aprendizaje en los primeros años, describiendo los beneficios que cada actividad puede brindar a los estudiantes de educación infantil. Se discute cómo el docente puede utilizar los recursos recreativos en sus prácticas pedagógicas, considerando que cada uno contribuye significativamente a la promoción del aprendizaje y la alfabetización efectivos. El foco de la investigación está en la perspectiva socio-interaccionista, presente en las experiencias que viven los niños a través de interacciones con el entorno, con otros niños, con adultos y consigo mismos. El estudio tuvo como procedimiento metodológico la investigación bibliográfica, a través de la revisión de la literatura en fuentes de información como libros, artículos científicos y trabajos académicos. Se puede considerar que se intentó reiterar la importancia de la alegría y los instrumentos pedagógicos como aliados al proceso de desarrollo de la lectura en el contexto escolar, con el objetivo de ofrecer propuestas para la viabilidad de una práctica pedagógica placentera, formativa y saludable para los niños, a través de la alegría y los múltiples lenguajes de los niños.
\end{abstract}

Palabras clave: Educación infantil; Literatura; Instrumentos de aprendizaje; Alegría.

\title{
1. Introdução
}

A pesquisa surgiu do interesse em se aprofundar nos estudos sobre a educação infantil, com ênfase no processo de desenvolvimento da leitura através do recurso mais compatível com a dinâmica de transformação cognitiva da criança, que é a ludicidade. Portanto, objetivou-se refletir e compreender a importância da ludicidade na aquisição da leitura, bem como apresentar meios lúdicos do tipo: literatura, jogos infantis e o brincar, expressões artísticas e práticas musicais.

Utilizou-se da metodologia do tipo pesquisa bibliográfica, trazendo uma abordagem qualitativa acerca do arcabouço teórico, bem como quantitativa frente diante do números de produções. Dado que se trata de uma pesquisa cuja natureza baliza todas as pesquisas (Fontana, 2018). Desta forma a coleta de dados realizou-se com uso da plataforma Google Acadêmico, cujo recorte temporal caracterizou-se no período de 2017 a 2021. Considerou-se que a relevância do tema se justifica devido a contemplar um assunto atual e de bastante repercussão no meio acadêmico e profissional, entre professores, embora seja matéria de estudo desde o início da história da educação.

O desenvolvimento da leitura parte da concepção do que vem a ser leitura. O fato é que existem diversas definições nos estudos da educação infantil sobre a leitura. E estas definições ainda nos trazem diferentes interpretações. As crianças começam a descobrir o mundo a partir das interações com elas mesmas, com outras crianças, com os adultos e mais tarde com os professores. A partir do que apreendem dessas interações, das descobertas, das experiências, da exposição de suas emoções, as crianças tornam-se indivíduos críticos e participantes do todo. Todo o conjunto de descobertas é adquirido através da leitura, do domínio da palavra (Kaercher, 2018).

Freire (1989, p. 09), afirma que "a leitura do mundo precede a leitura da palavra". O ato de ler não reflete apenas e inicialmente a leitura da palavra, mas primordialmente a "leitura" que a criança faz de tudo que está a sua volta, em seu mundo infantil, através das suas vivências aguçadas pelos sentidos, pela motricidade, pela linguagem oral e visual, sendo estas experiências suas primeiras leituras.

É por meio do universo da linguagem dos mais velhos, dos textos, das palavras, das letras circundados nas interações com as crianças, que são permitidas as manifestações do conjunto de gostos, crenças, valores e receios. Todo o contexto expresso por este conjunto, é a leitura de mundo. Entretanto, embora a criança, antes de tudo, já tenha a leitura de mundo, o desenvolvimento da leitura de fato somente se completa e se descortina ao indivíduo se o mesmo tiver o domínio do verbo, da palavra (Freire, 1989).

Pensa-se leitura em sua subjetividade, como algo que traz significado elevado para o indivíduo, pois através do desenvolvimento da leitura, são acrescentadas novas experiências, ideias e maneiras de compreender o mundo ao seu redor, tudo num movimento sistêmico que permite a criação e a reformulação de ideias e informações já existentes (Granados, 2020). 
Logo, tem-se a leitura como uma forma que o indivíduo desenvolve para dialogar com o texto impresso, buscando não apenas a decifração de um código de escrita, mas principalmente buscando a compreensão, a extração do significado do texto, a interpretação do que se lê.

Partindo desta ideia, infere-se que a leitura acarreta compreensão. Portanto, não se pode considerar que a criança que seja capaz apenas de decodificar as palavras de um texto, seja um indivíduo verdadeiramente letrado. Corroborando com o entendimento proposto, nesta monografia, traz-se a definição de leitura como:

um processo de compreensão abrangente que envolve aspectos neurológicos, naturais, econômicos e políticos. A correspondência entre os sons e os sinais gráficos pela decifração do código e compreensão do conceito ou ideia; corresponde a um ato de compreensão, ou seja, uma busca daquilo que o texto pode significar, da mesma forma que se procura extrair significado da linguagem falada; para que a leitura seja possível, é necessário que compreendamos símbolos (significantes) e aqueles que simbolizam (significados) (Ciríaco, 2020, p. 01).

A Educação Infantil, tal qual como conhecemos, de forma complementar à família, constitui-se realidade bastante atual. Isto porque durante muito tempo, na história da humanidade, a educação de crianças foi tida pela sociedade como responsabilidade integral das famílias ou dos grupos sociais, nos quais elas estavam inseridas. Durante longos períodos, inexistiam instituições responsáveis pela educação infantil e juntamente com os pais e comunidade (Bujes, 2018).

Entre os séculos XVI e XVII, surgiram as primeiras instituições de educação infantil. Já as creches e pré-escolas surgiram da necessidade advinda da revolução industrial, período em que as mulheres-mães passaram a trabalhar fora de casa e uma nova estrutura familiar se formava. Outra justificativa para o surgimento das escolas infantis foi traçada pela intervenção dos governos e das instituições filantrópicas, com o objetivo de transformar as crianças em seres sociais úteis, cidadãos, como forma de manter o progresso e a ordem social (Bujes, 2018). Mais tarde, ao final do século XIX e na metade do século XX, na Europa e no Brasil, respectivamente, as escolas foram expandindo-se e trazendo em suas práticas, as ideias e concepções dos psicólogos e dos médicos higienistas, os quais estudavam os comportamentos infantis e das famílias e assim determinavam o que seria um desenvolvimento mental normal ou patológico.

O número de pré-escolas e o nível de formação de seus docentes (já com magistério) foi ampliado a partir da promulgação da Constituição Federal de 1988, que conforme Oliveira (2020) “determinou que 50\% da aplicação obrigatória de recursos em educação fosse destinada a programas de alfabetização". Neste período, as creches já eram reconhecidas como instituição de educação, porém ficaram a margem por serem tidas como uma instituição de assistência social, procuradas em situações de exceção.

Os direitos das crianças promulgados pela Constituição foram concretizados quando o Estatuto da Criança e do Adolescente foi promulgado, em 1990. Foi neste momento que surgiram as primeiras discussões em defesa de um novo modelo de educação infantil através da proposta de aprovação da nova Lei de Diretrizes e Bases da Educação Nacional (LDB) - Lei n 9.394/1996, que estabelece as diretrizes e bases da educação nacional. Pode-se perceber, a partir de então, um avanço muito grande na educação, pois os conceitos de educação básica e de educação para formação profissional foram ampliados. Acompanhando esses avanços, as escolas tiveram suas responsabilidades aumentadas adquirindo assim, autonomia pedagógica, de gestão financeira e administrativa (Oliveira, 2020).

Atualmente, a LDB, dispõe no art. 29 que "A educação infantil, primeira etapa da educação básica, tem como finalidade o desenvolvimento integral da criança de até 5 (cinco) anos, em seus aspectos físico, psicológico, intelectual e social, complementando a ação da família e da comunidade" (Senado, 2020). 
A prática da função sociopolítica e pedagógica da Educação Infantil, prevista no art. 7 da Resolução do CNE/CEB n 05/2009, torna possível que as crianças em idade escolar se desenvolvam crítica, afetuosa, lúdica, colaborativa e solidariamente. A Resolução diz:

Artigo $7^{\circ} \mathrm{Na}$ observância destas Diretrizes, a proposta pedagógica das instituições de Educação Infantil deve garantir que elas cumpram plenamente sua função sociopolítica e pedagógica: I - oferecendo condições e recursos para que as crianças usufruam seus direitos civis, humanos e sociais; II - assumindo a responsabilidade de compartilhar e complementar a educação e cuidado das crianças com as famílias; III - possibilitando tanto a convivência entre crianças e entre adultos e crianças quanto a ampliação de saberes e conhecimentos de diferentes naturezas; IV promovendo a igualdade de oportunidades educacionais entre as crianças de diferentes classes sociais no que se refere ao acesso a bens culturais e às possibilidades de vivência da infância; V - construindo novas formas de sociabilidade e de subjetividade comprometidas com a ludicidade, a democracia, a sustentabilidade do planeta e com o rompimento de relações de dominação etária, socioeconômica, étnico-racial, de gênero, regional, linguística e religiosa.

Perpassando pela função sociopolítica e pedagógica da escola de educação infantil, a qual baseia-se em promover o desenvolvimento infantil, pensa-se sobre o processo de construção social da criança. Construção esta, que foi estudada pela psicologia do desenvolvimento humano, sendo uma de suas vertentes, a interacionista. Esta corrente defende que indivíduo e meio se relacionam de forma recíproca, ou seja, o homem se adapta ao ambiente e vice-versa. Assim também acontece com as crianças. Logo, esta pesquisa infere ao desenvolvimento infantil, as nuances da teoria sociointeracionista.

Neste contexto, fica claro o fato de que somos transformados ao passo em que os contextos culturais e históricos se modificam. Assim também acontece com as crianças (seres ativos) que são transformadas a partir de suas vivências e experiências adquiridas no mundo excessivamente mutável, juntamente com os adultos. Não são apenas receptoras de informações externas, mas as internalizam ativamente a partir do contato com seu próprio corpo (motricidade), e com o ambiente através das interações que realizam com adultos e outras crianças promovendo assim o desenvolvimento infantil.

Portanto, trata-se aqui o desenvolvimento infantil sob a perspectiva sociointeracionista de Piaget, Vygostsky e Wallon, que segundo Felipe (2018), considera o desenvolvimento das capacidades motoras, afetivas e cognitivas das crianças como um processo dinâmico, simultâneo e articulado. As práticas pedagógicas serão explanadas neste trabalho como um processo também sociointeracionista, uma vez que, conforme o objetivo geral, compreender a importância da ludicidade como instrumento de aprendizagem na aquisição da leitura e escrita é propor atividades pedagógicas que promovam a identidade pessoal, o desenvolvimento das competências, a construção de diferentes aprendizagens e a oportunidade para o contato social e a privacidade.

Mas como se desencadeia o processo de aprendizagem infantil? As crianças expressam-se por meio de múltiplas linguagens e estas são tão importantes quanto a linguagem escrita, inclusive a antecede. São presentes na vida das crianças e no cotidiano escolar. É importante considerar que as crianças usufruam do direito de manifestar-se através das diversas linguagens e, portanto, as escolas de educação infantil devem promover a aprendizagem infantil a partir das práticas pedagógicas que possibilitam a comunicação das crianças por meio destas linguagens (Pattuzzo, 2019).

As Diretrizes Curriculares Nacionais para a Educação Infantil (DNCEI) (Brasil, 2009) estabelecem orientações curriculares, princípios sobre a aplicação das práticas pedagógicas por meio das múltiplas linguagens das crianças nas atividades cotidianas das escolas de educação infantil. Estes princípios determinam os seis direitos de aprendizagens: conviver, brincar, participar, explorar, expressar e conhecer-se. Direitos estes que permitem as crianças manifestar e explorar todos os sentidos, como indivíduos criativos e sensíveis fazendo uso das diversas linguagens, interagindo com adultos e outras crianças, experimentando sensações corporais, sentimentos, manifestando-se artisticamente e produzindo conhecimentos e novas linguagens (Brasil, 2016). 
Seguindo as orientações dos documentos normativos mencionados para a Educação Infantil, propõe-se nesta monografia, que o processo de aprendizagem seja estudado sob a ótica de que as crianças necessitam de projetos pedagógicos que incluam atividades que envolvam abundantemente o uso das múltiplas linguagens (cores, imagens, desenhos, sons), todas presentes nas brincadeiras, nos jogos, no contar e ouvir histórias, no cantar e nas diversas manifestações artísticas. Ou seja, fazse necessária a prática da ludicidade na Educação Infantil.

Azevedo (2017) relatam o crescente interesse de pesquisadores em matérias e estudos acadêmicos pedagógicos que versam sobre a relevância da ludicidade no processo de ensino-aprendizagem. Logo, pode-se considerar que a literatura é assertiva ao tratar da prática da ludicidade na Educação Infantil, afirmando que as crianças utilizam diversas linguagens abundantemente para se comunicarem. Linguagens essas representadas por imagens, cores, desenhos e os sons. No ambiente escolar, deve-se promover a ludicidade como instrumento pedagógico, visando explorar as diversas formas de expressão das crianças através do cantar, do pintar, do brincar, do dançar, para que interajam consigo mesmas, com os colegas e com os professores (Pattuzzo, 2019).

A Base Nacional Comum Curricular (BNCC) estabeleceu que na Educação Infantil deve-se garantir os seis direitos de aprendizagens e desenvolvimento. São eles: conviver, brincar, participar, explorar, expressar e conhecer-se. Assim, garantidos estes direitos às crianças em idade escolar, permite-se que as mesmas se expressem com criatividade, sensibilidade, emitindo opiniões, sentimentos, desejos, narrativas. E ainda adquiram conhecimentos construídos a partir das variadas experiências, englobando a produção de linguagens e a utilização das manifestações artísticas (Brasil, 2017; Dornelles, 2018).

Neste contexto, o instrumento pedagógico que acredita-se ser o mais próximo do alcance do uso das múltiplas linguagens e, portanto, do processo de aprendizagem infantil, é a ludicidade, a qual será tratada nesta monografia como instrumento pedagógico que envolve atividades de interação social por meio de experiências concretas vividas pelos alunos, bem como de experiências que recebem através do outro (colegas, professores, pais, grupo social). Busca-se, então, trabalhar com a ludicidade advinda da literatura (ouvir e contar histórias); dos jogos infantis; do brincar; do uso de materiais artísticos; das práticas musicais.

\section{Metodologia}

A pesquisa é do tipo natureza bibliográfica quanto à coleta de dados determinada (Menezes; Duarte; Carvalho \& Souza, 2019). Desta forma, pode-se considerar, que dados objetivos de maneira descritiva, bem como analítica, entende-se como pesquisa de abordagens qualitativa e quantitativa (Mazo; Oliveira \& Tomazzoni, 2021). Inclui-se também dado sua natureza, o método exploratório (Pereira et al.,2018).

Foram utilizadas como fontes de informação livros, trabalhos de conclusão de curso, documentos, artigos de periódicos, artigos de anais de eventos e e-book. Os artigos científicos e os trabalhos acadêmicos foram recuperados por meio da plataforma Google Acadêmico, das bases de dados de periódicos online e de repositórios institucionais de Instituições de Ensino Superior (IES). Os materiais utilizados no estudo foram escolhidos de acordo com as palavras-chave ensino infantil, alfabetização, letramento, instrumentos de aprendizagem e ludicidade, todos publicados entre os anos de 2017 e 2021, afim de trazer mais atualidade ao trabalho; além de terem sido feitas seleções de variados autores para dar melhor embasamento ao referencial teórico, por meio das citações e referências bibliográficas, todas elaboradas dentro das normas da APA.

\section{Resultados e Discussão}

A literatura acerca da importância da ludicidade para o desenvolvimento da leitura e da aprendizagem na educação infantil é vasta, por se tratar de uma temática presente desde o início dos estudos sobre alfabetização e letramento, ao longo de 
Research, Society and Development, v. 11, n. 1, e52011125228, 2022

(CC BY 4.0) | ISSN 2525-3409 | DOI: http://dx.doi.org/10.33448/rsd-v11i1.25228

toda história da Educação. Com a revisão de literatura realizada pode-se comprovar que a aplicação da ludicidade através dos recursos lúdicos explanados na pesquisa, constitui-se uma forte aliada no processo de desenvolvimento das linguagens, da leitura e da aprendizagem infantil.

Os estudos mostram que a ludicidade é estudada não somente na área de educação, mas também em outras áreas como psicologia, história e artes. Isto porque a ludicidade infere ao indivíduo a oportunidade de desenvolvimento em todas as áreas humanas (psíquica, social, educacional e cultural). Logo, o envolvimento e execução de práticas pedagógicas por meio da literatura (ouvir, contar e partilhar histórias), dos jogos infantis e do brincar, das expressões artísticas e das práticas musicais, na educação infantil, é sempre proposta na Pedagogia até nos dias atuais.

Os estudos acerca do tema, fontes para os resultados apresentados, foram retirados de materiais bibliográficos como livros, artigos científicos e trabalhos acadêmicos online. Dentre as fontes pesquisadas, destaca-se o livro Educação Infantil: pra que te quero? que reúne diversos textos em capítulos, de variados autores sobre educação infantil e a aplicação da ludicidade e de seus instrumentos nas práticas pedagógicas como aliada no processo de desenvolvimento da leitura e da aprendizagem infantil. Desta forma, as fontes em destaque constam na Tabela 1. 
Tabela 1 - Fontes bibliográficas em destaque.

\begin{tabular}{|c|c|c|c|}
\hline AUTOR/ANO & $\begin{array}{c}\text { TÍTULO } \\
\end{array}$ & METODOLOGIA & CARACTERÍSTICAS \\
\hline $\begin{array}{c}\text { Cartaxo; } \\
\text { Smaniotto \& } \\
\text { Fontana (2020) }\end{array}$ & $\begin{array}{l}\text { As facetas da } \\
\text { alfabetização nos cursos } \\
\text { de pedagogia: desafios } \\
\text { para a formação do } \\
\text { professor }\end{array}$ & \multirow{4}{*}{$\begin{array}{l}\text { Revisão de literatura em } \\
\text { publicações que constam as } \\
\text { palavras-chave: ensino } \\
\text { infantil; alfabetização; } \\
\text { letramento; instrumentos de } \\
\text { aprendizagem; ludicidade. }\end{array}$} & \multirow{4}{*}{$\begin{array}{l}\text { Pode-se comprovar sobre letramento que: Letramento e } \\
\text { alfabetização não são a mesma coisa. Alfabetizar é usar as } \\
\text { técnicas de ensinar a leitura e a escrita, através dos } \\
\text { símbolos gráficos; enquanto Letrar é fazer com que o } \\
\text { processo de leitura e escrita promova a inserção e } \\
\text { interação das crianças nas diferentes práticas sociais que } \\
\text { envolvem a escrita }\end{array}$} \\
\hline $\begin{array}{c}\text { Camargo; } \\
\text { Cardoso \& } \\
\text { Monteiro (2018) }\end{array}$ & $\begin{array}{l}\text { A } \\
\text { escrita e a leitura na } \\
\text { educação infantil: uma } \\
\text { perspectiva } \\
\text { letramento. }\end{array}$ & & \\
\hline $\begin{array}{c}\text { Lima \& } \\
\text { Casagrande } \\
(2020)\end{array}$ & $\begin{array}{l}\text { Alfabetização } \\
\text { letramento na educação } \\
\text { infantil. }\end{array}$ & & \\
\hline Ciríaco (2020) & $\begin{array}{l}\text { A leitura e a escrita no } \\
\text { professo de alfabetização }\end{array}$ & & \\
\hline Oliveira (2020) & Educação Infantil & \multirow{2}{*}{$\begin{array}{l}\text { Revisão de literatura em } \\
\text { publicações que constam as } \\
\text { palavras-chave: ensino } \\
\text { infantil; alfabetização; } \\
\text { letramento; instrumentos de } \\
\text { aprendizagem; ludicidade. }\end{array}$} & \multirow[b]{2}{*}{$\begin{array}{l}\text { Pode-se comprovar o processo de desenvolvimento das } \\
\text { linguagens das crianças, desde quando muito pequenos. } \\
\text { Ambos discorrem sobre a linguagem motora, a } \\
\text { motricidade. Afirmam que as crianças ao se manifestar } \\
\text { através da motricidade, adquirem a percepção sensorial. }\end{array}$} \\
\hline Miranda (2018) & $\begin{array}{l}\text { Motricidade humana e } \\
\text { percepção sensorial Em } \\
\text { crianças até } 2 \text { anos de } \\
\text { idade }\end{array}$ & & \\
\hline Celestino (2019) & $\begin{array}{l}\text { A oralidade infantil e } \\
\text { desenvolvimento } \\
\text { cognitivo a partir da } \\
\text { prática docente }\end{array}$ & \multirow[b]{2}{*}{$\begin{array}{l}\text { Revisão de literatura em } \\
\text { publicações que constam as } \\
\text { palavras-chave: ensino } \\
\text { infantil; alfabetização; } \\
\text { letramento; instrumentos de } \\
\text { aprendizagem; ludicidade. }\end{array}$} & \multirow[b]{2}{*}{$\begin{array}{l}\text { Tratam sobre a linguagem oral, ou verbal, considerando a } \\
\text { percepção e produção dos sons da fala como primordiais } \\
\text { para a manifestação da linguagem oral e o } \\
\text { desenvolvimento linguístico, este por sua vez constitui-se } \\
\text { um processo sócio-histórico. }\end{array}$} \\
\hline $\begin{array}{l}\text { Saccomani } \\
\quad(2018)\end{array}$ & $\begin{array}{l}\text { A importância da } \\
\text { educação pré-escolar } \\
\text { para o desenvolvimento } \\
\text { da linguagem oral e } \\
\text { escrita: contribuições à } \\
\text { luz da pedagogia } \\
\text { histórico-crítica e da } \\
\text { psicologia histórico- } \\
\text { cultural }\end{array}$ & & \\
\hline Rocha (2017) & $\begin{array}{l}\text { A importância do lúdico } \\
\text { na educação infantil: } \\
\text { uma análise a partir da } \\
\text { concepção } \\
\text { professores. }\end{array}$ & \multirow{5}{*}{$\begin{array}{l}\text { Revisão de literatura em } \\
\text { publicações que constam as } \\
\text { palavras-chave: ensino } \\
\text { infantil; alfabetização; } \\
\text { letramento; instrumentos de } \\
\text { aprendizagem; ludicidade. }\end{array}$} & \multirow{5}{*}{$\begin{array}{l}\text { Discorreram sobre ludicidade, conceitos de lúdico e } \\
\text { brincadeiras. Fizeram um destaque em suas pesquisas } \\
\text { sobre a atuação docente na educação infantil com a } \\
\text { ludicidade em suas práticas pedagógicas. Pode-se inferir } \\
\text { de seus textos, que a ludicidade e a utilização dos recurso } \\
\text { lúdicos são, desde muito tempo, temas de estudos e } \\
\text { investigações científicas nas áreas de educação, história e } \\
\text { psicologia. Sua importância é retratada tanto para o } \\
\text { processo de alfabetização, quanto para promoção da } \\
\text { socialização e até da ressocialização de crianças que } \\
\text { vivem na marginalidade e encontram-se em casas de } \\
\text { recuperação social. }\end{array}$} \\
\hline Silva (2019) & $\begin{array}{l}\begin{array}{l}\text { O lúdico } \\
\text { infantil: } \\
\text { presentes } \\
\text { docente. }\end{array} \\
\text { do }\end{array}$ & & \\
\hline $\begin{array}{c}\text { Freitas \& } \\
\text { Becker (2020) }\end{array}$ & $\begin{array}{l}\text { A importância do lúdico } \\
\text { e o papel do professor na } \\
\text { Educação infantil: uma } \\
\text { revisão bibliográfica em } \\
\text { Periódicos nacionais }\end{array}$ & & \\
\hline Garcia (2019) & $\begin{array}{l}\text { O lúdico da matemática } \\
\text { na educação infantil }\end{array}$ & & \\
\hline $\begin{array}{l}\text { Souza; Juvêncio } \\
\text { \& Moreira } \\
\text { (2018) }\end{array}$ & $\begin{array}{ll}\text { Jogos e } & \text { brincadeiras: o } \\
\text { lúdico } & \text { na educação } \\
\text { infantil } & \end{array}$ & & \\
\hline Kaercher (2018) & E por falar em Literatura & $\begin{array}{l}\text { Revisão de literatura em } \\
\text { publicações que constam as } \\
\text { palavras-chave: ensino } \\
\text { infantil; alfabetização; } \\
\text { letramento; instrumentos de } \\
\text { aprendizagem; ludicidade. }\end{array}$ & $\begin{array}{l}\text { Discorrem sobre o recurso lúdico Literatura, através das } \\
\text { ações de ouvir, contar e partilhar histórias. Consideram } \\
\text { essas ações como fontes de criatividade, criticidade, } \\
\text { socialização e aprendizagem; e unindo todos estes } \\
\text { aspectos certamente a literatura contribuirá para a } \\
\text { alfabetização. Propõem que os professores tenham o } \\
\text { instrumento livro como fonte principal de aplicabilidade } \\
\text { da ludicidade por meio da literatura em sala de aula. }\end{array}$ \\
\hline Oliveira \& & $\begin{array}{lll}\text { A } & \text { literatura infantil }\end{array}$ & & \\
\hline
\end{tabular}




\begin{tabular}{|c|c|c|c|}
\hline $\begin{array}{l}\text { Serighelli } \\
(2020)\end{array}$ & $\begin{array}{l}\text { enquanto estratégia } \\
\text { pedagógica no processo } \\
\text { de formação cidadã com } \\
\text { alunos da educação } \\
\text { básica }\end{array}$ & & \\
\hline Santos (2018) & $\begin{array}{l}\text { Promovendo o } \\
\text { desenvolvimento do faz- } \\
\text { de-conta na Educação } \\
\text { Infantil }\end{array}$ & \multirow{4}{*}{$\begin{array}{l}\text { Revisão de literatura em } \\
\text { publicações que constam as } \\
\text { palavras-chave: ensino } \\
\text { infantil; alfabetização; } \\
\text { letramento; instrumentos de } \\
\text { aprendizagem; ludicidade. }\end{array}$} & \multirow{4}{*}{$\begin{array}{l}\text { Discorrem sobre o assunto considerando os jogos infantis } \\
\text { como instrumento da ação brincar, pois esta ação é, como } \\
\text { comprovado em diversas pesquisas em educação e outras } \\
\text { áreas, o maior instrumento de motivação da aprendizagem } \\
\text { infantil, o aprender brincando é natural do comportamento } \\
\text { das crianças. Um destaque maior é dado e inclusive } \\
\text { utilizado nesta monografia, para os jogos simbólicos, } \\
\text { estudados por Jean Piaget e detalhado no texto de Santos } \\
\text { (2018), autor de destaque no subitem "Jogos simbólicos", } \\
\text { com a tabela de abordagem evolutiva da aprendizagem } \\
\text { infantil por meio de tal recurso. }\end{array}$} \\
\hline $\begin{array}{l}\text { Martins, Costa } \\
\& \text { Souza }(2020)\end{array}$ & $\begin{array}{l}\text { A importância dos jogos } \\
\text { e das brincadeiras na } \\
\text { Educação Infantil }\end{array}$ & & \\
\hline Andrade (2018) & $\begin{array}{l}\text { A importância do lúdico } \\
\text { na educação infantil: um } \\
\text { estudo de caso em uma } \\
\text { creche pública }\end{array}$ & & \\
\hline $\begin{array}{c}\text { Freitas \& } \\
\text { Becker }(2020)\end{array}$ & $\begin{array}{l}\text { A importância do lúdico } \\
\text { e o papel do professor na } \\
\text { Educação infantil: uma } \\
\text { revisão bibliográfica em } \\
\text { Periódicos nacionais }\end{array}$ & & \\
\hline Mangoni (2019) & $\begin{array}{l}\text { A expressão artística: } \\
\text { uma compreensão que } \\
\text { vai além do lápis e do } \\
\text { papel }\end{array}$ & \multirow{2}{*}{$\begin{array}{l}\text { Revisão de literatura em } \\
\text { publicações que constam as } \\
\text { palavras-chave: ensino } \\
\text { infantil; alfabetização; } \\
\text { letramento; instrumentos de } \\
\text { aprendizagem; ludicidade. }\end{array}$} & \multirow{2}{*}{$\begin{array}{l}\text { Ao discorrer sobre a ludicidade por meio do recurso } \\
\text { Expressões artísticas com a utilização de diversificados } \\
\text { materiais além do lápis e do papel, temos três autores que } \\
\text { tratam deste recurso lúdico de forma que ratifica o } \\
\text { entendimento desta monografia. Os autores comparam o } \\
\text { fazer artístico com o ensinar a ler, pois consideram que é } \\
\text { necessário tanto para um quanto para o outro, é necessário } \\
\text { que seja promovida em suas práticas a criatividade, a } \\
\text { criticidade, a socialização, e principalmente a } \\
\text { interpretação. Um destaque é dado ao texto de Gomes } \\
\text { (2018), ao afirmar que é preciso transformar o brincar em } \\
\text { expressão. Para ela, isso se faz através das expressões } \\
\text { artísticas como recurso lúdico. A autora nos apresenta as } \\
\text { propostas de condução da ação artística na educação } \\
\text { infantil. }\end{array}$} \\
\hline Souza (2017) & $\begin{array}{l}\text { A importância da } \\
\text { disciplina de artes na } \\
\text { educação: capacidade e } \\
\text { criatividade das crianças }\end{array}$ & & \\
\hline $\begin{array}{c}\text { Kastein \& } \\
\text { Pacífico }(2018)\end{array}$ & $\begin{array}{l}\text { A formação musical na } \\
\text { educação infantil: a } \\
\text { questão docente e as } \\
\text { possibilidades } \\
\text { musicalização }\end{array}$ & $\begin{array}{l}\text { Revisão de literatura em } \\
\text { publicações que constam as } \\
\text { palavras-chave: ensino } \\
\text { infantil; alfabetização; } \\
\text { letramento; instrumentos de } \\
\text { aprendizagem; ludicidade. }\end{array}$ & $\begin{array}{l}\text { As práticas musicais, como recurso lúdico na educação } \\
\text { infantil é estudada pelos autores como uma forma de } \\
\text { aprender brincando, gerando diálogos entre as crianças e } \\
\text { suas interações. Para os autores, a música promove o } \\
\text { desenvolvimento das características humanas físicas, } \\
\text { mentais, sociais, emocionais e espirituais. Pode-se } \\
\text { compreender os benefícios da música para os aspectos } \\
\text { humanos físico, psíquico, cognitivo/mental e educacional. } \\
\text { A criança pode desenvolver a partir da musicalização a } \\
\text { noção do tempo e do espaço, bem como as habilidades } \\
\text { lógico-matemáticas e linguísticas. }\end{array}$ \\
\hline $\begin{array}{l}\text { Maffioletti } \\
\text { (2018) }\end{array}$ & $\begin{array}{l}\text { Práticas musicais na } \\
\text { escola infantil }\end{array}$ & & \\
\hline Menezes (2019) & $\begin{array}{l}\text { A música e o } \\
\text { desenvolvimento } \\
\text { criança da educação } \\
\text { infantil }\end{array}$ & & \\
\hline
\end{tabular}


Toda literatura encontrada a respeito do tema ludicidade na educação infantil, considerando os descritores utilizados nas pesquisas, apresentam resultados e discussões favoráveis à utilização da ludicidade como aliada na prática pedagógica em sala de aula e, portanto, no processo de desenvolvimento da leitura na educação infantil, objeto de estudo deste trabalho monográfico.

Analisando-se os estudos de Cartaxo, Smaniotto \& Fontana (2020); Camargo, Cardoso \& Monteiro (2018); Lima \& Casagrande (2020); Ciríaco (2020); Oliveira (2020); Miranda (2018); Celestino (2019) e Saccomani (2018), sobre alfabetização e letramento; e linguagens infantis - da motricidade à linguagem escrita - pode-se compreender a diferença entre alfabetização e letramento e o papel das linguagens infantis para a construção de significados, e não apenas para o aprender a decodificar o alfabeto de uma língua. Pois, como evidenciado, o letramento vem antes mesmo da alfabetização, uma vez que a "leitura" de mundo antecede a apreensão de significados, da leitura e da escrita, conforme dito por Paulo Freire.

As propostas e resultados apresentados pelas publicações referenciadas neste trabalho, mais precisamente os estudos de Rocha (2017); Silva (2019); Freitas \& Becker (2020); Garcia (2019); Souza, Juvêncio \& Moreira (2018) entendem a ludicidade, a partir da utilização eficiente dos recursos lúdicos apresentados neste estudo, como uma alternativa e prática pedagógica:

- Eficaz no desenvolvimento da criança em suas capacidades humanas, psíquicas e mentais, sensoriais, cognitivas, históricas, sociais, culturais e de aprendizagem;

- Capaz de ajudar no combate ao analfabetismo, uma vez que, aliada ao processo de aprendizagem em sua totalidade, propicia oportunidades de desenvolvimento da leitura e, portanto, da alfabetização e letramento;

- Capaz de influenciar no combate ao retorno das crianças em vulnerabilidade social à marginalidade;

- Capaz de despertar e ampliar as manifestações das múltiplas linguagens infantis.

- Presente em todas as temáticas sobre alfabetização e letramento, aprendizagem e desenvolvimento infantil, nas áreas de conhecimento como educação principalmente, história e psicologia.

Com relação aos recursos lúdicos explanados neste trabalho, cada qual com sua especificidade, é possível afirmar que todos apresentam considerações assertivas na literatura existente em meio acadêmico e demais espaços de pesquisa nas áreas de educação, história e psicologia.

Mencionado anteriormente, reforça-se que houve um destaque maior para o livro Educação Infantil: pra que te quero? com os textos de Kaercher; Santos; Gomes e Maffioletti (2018), os quais serviram de principal fonte de informação para desenvolvimento dos subitens que versam sobre os recursos lúdicos: Literatura (ouvir, contar e partilhar histórias), Jogos Infantis e o brincar; Expressões artísticas - uso de materiais artísticos; e Práticas musicais. No entanto, os demais materiais bibliográficos utilizados na pesquisa corroboram a posição teórica desta monografia.

Cabe salientar, para finalizar esta discussão, que todas as publicações utilizadas trazem em suas fundamentações teóricas a perspectiva sociointeracionista, assim como a percepção deste estudo.

\subsection{Alfabetização e letramento na educação infantil}

Historicamente, o termo letramento surgiu na década de 1980, em várias partes do mundo. Existia uma necessidade de dar nomes a diversas práticas sociais de escrita e leitura que incentivam e levam base para o domínio do sistema linguístico e domínio da escrita (Cartaxo; Smaniotto \& Fontana, 2020).

O letramento não é a alfabetização em si, ele é incluído no processo de alfabetização como um meio de educar. Letrar se torna uma parte muito importante, sendo um processo de ensinar a criança dentro de seu determinado contexto; considerando a sua cultura, a forma de viver da criança e ensinar a interpretar, de acordo com cada realidade. Letrar é fazer 
Research, Society and Development, v. 11, n. 1, e52011125228, 2022

(CC BY 4.0) | ISSN 2525-3409 | DOI: http://dx.doi.org/10.33448/rsd-v11i1.25228

com que a escrita e a leitura façam parte da vida da criança. Esse processo é anterior ao colégio e se completa após o contato da criança no convívio escolar (Camargo; Cardoso \& Monteiro, 2018).

A perspectiva de letramento para as pesquisas brasileiras, gira em torno de fazer com que a criança seja inserida nas práticas sociais, desenvolvendo mais autonomia por meio do domínio da linguagem. Os conceitos de alfabetização e letramento e, ao mesmo tempo, suas relações de interdependência, passamos a abordar esse processo - o alfabetizar letrando a partir das múltiplas facetas que o constituem (Cartaxo; Smaniotto \& Fontana, 2020).

A alfabetização é considerada por muitos estudiosos da educação como um processo que apresenta uma complexidade em seu desenrolar e possui diversas facetas, as quais trazem especificidades inerentes ao ser humano: facetas psicológicas, psicolinguísticas, linguísticas e sociolinguísticas. Isto refere-se ao fato de que cada criança possui um nível de compreensão, logo o desenvolvimento da leitura e da escrita será variada para cada criança (Lima \& Casagrande, 2020).

Discussões sobre a alfabetização e formação dos professores, no início da vida da criança e continuamente, tem enfatizado que práticas de alfabetização devem acontecer em torno do processo de letramento. Sendo assim, alfabetizar letrando. A alfabetização e letramento vem do processo de aprender a ler, escrever e entender, tendo o letramento um caráter social (Cartaxo; Smaniotto \& Fontana, 2020).

Alfabetização é o processo de ler, escrever, conhecer e entender o alfabeto e o momento de adquirir práticas de leitura. Durante o processo de alfabetização, o sujeito, individualmente, conhece o funcionamento do sistema alfabéticoortográfico de escrita (estabelece relação fonema-grafema, codifica, decodifica...) e passa a dominá-lo, o que permite que leia e escreva. Todavia, dominar o sistema de escrita não é garantia de inserção e interação nas diferentes práticas sociais que envolvem a escrita. Para essa perspectiva, surge o termo letramento (Cartaxo; Smaniotto \& Fontana, 2020).

No Brasil, os níveis de analfabetismo são altos, tanto quanto os problemas do ensino público. O contexto traz discussões entre estudiosos da educação sobre a problemática buscando promover uma possível revolução ou ao menos uma melhoria na educação do país. Os problemas educacionais são atuais, embora o processo de alfabetização seja uma discussão bastante antiga entre os assuntos pedagógicos.

Ao longo da história da educação, pensou-se em muitas formas de alfabetizar, as quais apresentavam cada uma, um ponto de vista no aprendizado, entretanto, todas sob uma concepção ainda atual sobre como se desenvolve o processo de aprendizado do aluno, e não sobre como o professor conduz o ensino e suas práticas pedagógicas (CIRÍACO, 2020).

\subsection{Da motricidade à linguagem escrita}

As crianças, tratadas aqui sob a perspectiva sociointeracionista, se desenvolvem a partir de suas trocas de experiências com os adultos e com o espaço social em que vivem. Portanto, pode-se dizer que assim também acontece com o processo de Alfabetização e Letramento, pois as crianças iniciam o contato com o mundo da escrita desde muito cedo, interagindo com familiares e grupos sociais, inicialmente através da construção das linguagens motora, oral e visual, sendo esta muito forte ultimamente, através dos recursos tecnológicos como televisão, celulares e demais recursos (Oliveira, 2020).

Antes de discorrer sobre as linguagens oral e visual, faz-se importante contextualizar o desenvolvimento da motricidade na infância, o qual permite nos primeiros meses, a comunicação através dos gestos, da locomoção e de posturas que vão se ampliando, conforme o crescimento da criança. É ao desenvolver a motricidade que a criança recebe informações externas e de seu próprio corpo, as quais são necessárias para fazer suas próprias interpretações e organizações dos elementos e do espaço, formulando uma representação de tudo a sua volta.

Quando a criança está desenvolvendo sua motricidade, isto desde a vida uterina, sua linguagem oral ainda não está formada. Logo, ela inicia sua comunicação com o mundo através da linguagem motora adquirindo a percepção sensorial, sendo esta muito importante para o desenvolvimento infantil. Nesta fase, o processo de aprendizagem das crianças tem início ao 
Research, Society and Development, v. 11, n. 1, e52011125228, 2022

(CC BY 4.0) | ISSN 2525-3409 | DOI: http://dx.doi.org/10.33448/rsd-v11i1.25228

vivenciar e agir no mundo através dos sentidos. Na prática com as crianças, na educação infantil, a percepção sensorial deve ser bem estimulada para que, quando adultos, as crianças tenham adquirido capacidades físicas, cognitivas e sociais bem estruturadas e ricas (Miranda, 2018). Através da manipulação de objetos de cores, formas, sons, pesos, texturas e volumes diferentes, a criança adquire percepções que permitem diferenciar o que está perto ou longe, ter ideias de ordem e inclusão (dentro e fora), de limites espaciais em que se encontra.

Visto que a criança já adquiriu o desenvolvimento da linguagem através da motricidade, parte-se para o segundo recurso no processo de desenvolvimento da alfabetização e letramento na infância, que é a linguagem oral, sob a ideia de que a fala é uma forma muito especial de se comunicar, expressão específica do ser humano, e um pré-requisito para que aconteçam as primeiras interações entre adultos e criança, embora que já temos ciência da importância dos gestos, do toque e das percepções adquiridas pelas crianças através da motricidade a priori. Entretanto, é através da linguagem oral que acontece o desenvolvimento linguístico, o qual é constituído de diversos sistemas simbólicos elaborados socialmente (Celestino, 2019).

A aquisição da linguagem é um processo sócio-histórico e, portanto, está relacionada às interações de qualidade entre adultos x criança; criança x criança; criança $\mathrm{x}$ recursos tecnológicos (TV e outros). Estas diferentes interações geram um processo de comunicação e as crianças passam a elaborar seus próprios questionamentos sobre o mundo e apropria-se dele e das regras de ação e comunicação, elaborando suas produções verbais primárias (Oliveira, 2020).

Segundo Celestino (2019), as interações vivenciadas pelas crianças desde o nascer, quando bebês, já associam os sons para comunicar-se com os adultos e estes fazem interpretações dessa linguagem, gerando assim um significado e permitindo que as crianças expressem sua própria língua. Portanto, tem-se a linguagem oral formal ou informal como uma das mais importantes formas de expressão.

O precursor direto da linguagem verbal, segundo Oliveira (2020) é o desenvolvimento da capacidade de perceber e produzir sons da fala. Isto se explica porque logo ao nascer, os bebês reagem a sons maternos, na interação íntima entre mãe $\mathrm{x}$ bebê. O desenvolvimento da percepção dos sons da fala levará a criança a identificar e diferenciar objetos, a entender imitação e memória e todas aquisições que levarão a criança a reproduzir gestos e padrões vocais. Nesta fase, que se refere ao primeiro ano de vida, a criança já reproduz as primeiras palavras e já atende ao "sim" e ao "não". A partir de então, naturalmente surgem diferenciadas palavras em seu vocabulário.

Saccomani (2018) corrobora este contexto afirmando que a linguagem verbal antecede a linguagem escrita justamente pelo fato de que os sons da fala se tornam o objeto de atenção da criança, nesta fase da infância, permitindo o domínio da estrutura sonora das diversas unidades de composição das palavras, antes mesmo da aquisição da linguagem escrita. A criança desenvolve o sistema linguístico a partir dos quatro a cinco anos de idade, quando passa a ter domínio primordial do sistema fonológico, passa a atribuir sentido às palavras e as aplica de forma correta, comunicando-se mais claramente em suas interações sociais.

Passando dos cinco anos, o sistema linguístico infantil apresenta mais complexidade em certas estruturas linguísticas, já surgem a coesão nas falas das crianças e as mesmas passam a brincar com a linguagem, identificando o que está certo ou errado em seus discursos. Toda a evolução do sistema linguístico será enriquecida através do desenvolvimento cognitivo das crianças juntamente com suas experiências culturais e vivências na educação infantil, na escola (Oliveira, 2020).

Desenvolvido o sistema linguístico através da motricidade juntamente com as linguagens oral e visual, passa-se a dar continuidade ao processo de alfabetização e letramento através da leitura e da linguagem escrita, as quais estão presentes na vida do ser humano desde o início da infância. Está na constituição que toda criança tem direito ao acesso à cultura letrada desde o início da vida, nos primeiros anos de vida e o processo de leitura e escrita deve ser ofertado na educação infantil, uma vez que o desenvolvimento cognitivo, como já exposto, inicia-se no ambiente familiar e social (Camargo; Cardoso \& 
Monteiro, 2018). Neste contexto, a criança adentra à escola de educação infantil já com uma bagagem, um conhecimento inicial da leitura e da linguagem escrita, com certo nível de letramento, embora ainda não alfabetizada.

\subsection{Estimulando a leitura por meio de práticas pedagógicas}

O papel fundamental da educação infantil é promover o desenvolvimento da criança. Cabe ressaltar que, sob uma perspectiva interacionista do envolvimento da criança com o mundo e consigo mesma, pode-se buscar estratégias para auxiliar no processo de ensino e aprendizagem através da ludicidade em sala de aula, fazendo os alunos interagirem e se desenvolverem cognitiva e socialmente. Assim também, pode-se explorar o mundo infantil com atividades lúdicas bem realizadas e elaboradas, e a partir delas, promover o desenvolvimento da leitura. Na Educação Infantil, de acordo com a Base Nacional Comum Curricular (BNCC, 2019),

o corpo das crianças ganha centralidade, pois ele é o partícipe privilegiado das práticas pedagógicas de cuidado físico, orientadas para a emancipação e a liberdade, e não para a submissão. Assim, a instituição escolar precisa promover oportunidades ricas para que as crianças possam, sempre animadas pelo espírito lúdico e na interação com seus pares, explorar e vivenciar um amplo repertório de movimentos, gestos, olhares, sons e mímicas com o corpo, para descobrir variados modos de ocupação e uso do espaço com o corpo (p. 41).

Segundo Rocha (2017), a palavra Lúdica, em sua origem, consiste em um adjetivo da língua portuguesa derivada do latim "ludus" e significa toda atividade que advém de brincadeiras, jogos, recreação, entretenimento como um todo. As atividades lúdicas na educação infantil não se trata apenas de brincar, jogar, recrear como a criança faz em sua própria casa ou em locais de lazer, e sim da promoção de momentos de experiências, ações vivenciadas repletas de significado que estimulam a curiosidade, acarretando no desenvolvimento cognitivo e social, e portanto, auxiliando no processo de ensino e aprendizagem infantil.

No caminho percorrido pela história, o lúdico foi matéria de estudo e de investigação em áreas do conhecimento como história, psicologia e educação. E em todas essas, buscou-se a identificação e a compreensão sobre como e por que a ludicidade exerce influência no processo de ensino e aprendizagem. Os estudiosos também buscaram identificar o papel dos professores tanto na criação e no uso das atividades lúdicas, quanto na criação dos espaços lúdicos (Silva, 2019).

Para além da aprendizagem educacional, o lúdico permite que as crianças se apropriem ou readquiram a autoestima, quando estas vivem em situações de abandono e vulnerabilidade, em ambientes como abrigos e orfanatos, promovendo inclusive sua reintegração social. Neste contexto de marginalidade, pode-se através da ludicidade, desenvolver o senso de responsabilidade e trabalho educando as crianças a utilizar e valorizar brinquedos, jogos, as brincadeiras, sem se sentirem donos dos materiais, evitando assim, o hábito de trazer para si o que não é seu. Usufruir sem possuir (Freitas \& Becker, 2020).

Sendo o brincar, a mais importante linguagem das crianças na Educação Infantil, a ludicidade torna-se um instrumento de aprendizagem importante entre professores e alunos, pois propicia à criança uma maneira divertida e diferente de aprender. O lúdico pode ser utilizado habitualmente no ensino da matemática por exemplo, tornando a matéria mais divertida, dinâmica e significativa, melhorando até mesmo o desempenho das crianças na disciplina, que para muitos é considerada de difícil compreensão (Garcia, 2019).

A ludicidade contribui até mesmo para o processo de alfabetização, pois a partir das brincadeiras, as crianças desenvolvem aspectos de interação, socialização, conhecimento e, portanto, leitura e escrita. Assim também, os jogos, o cantar, os materiais artísticos, a literatura, os recursos musicais, todos contribuem de forma lúdica para uma aprendizagem eficaz (Souza; Juvêncio \& Moreira, 2018). 
Partindo do pressuposto de aprendizagem efetiva e alfabetização possível através da ludicidade como instrumento pedagógico, reafirma-se que este estudo busca trabalhar com a ludicidade advinda de recursos como a literatura (ouvir, contar e partilhar histórias); dos jogos infantis; do brincar; do uso de materiais artísticos; das práticas musicais. Recursos estes explanados a seguir.

\subsection{Literatura (ouvir, contar e partilhar histórias)}

A literatura surgiu da necessidade que o ser humano tem de ouvir, contar e também de compartilhar histórias ou estórias sua e dos outros. As histórias contadas nas poesias ou nos romances, ou seja, em prosa ou verso, permitiram que a humanidade contribuísse para a formação da própria identidade sociopolítico cultural. Portanto, a literatura - através do ouvir e contar histórias - permitiu segundo Kaercher (2018, p. 81), "que a humanidade passasse, de geração a geração, sua história seus feitos, suas decepções, seus amores, seus sonhos, seus temores, suas esperanças...”

A aplicação da literatura na educação infantil é amplamente difundida e indicada pelos estudos na área de pedagogia e afins, sob uma visão que está de acordo com a perspectiva sociointeracionista trabalhada nesta monografia. Isto porque acredita-se que também a literatura como recurso lúdico na prática pedagógica, por meio do ouvir, contar e partilhar histórias, necessita para exercer sua função no desenvolvimento da leitura infantil, que haja interações entre criança x criança, criança e adultos, e a criança em si mesma. Mais uma vez ressalta-se que o aprendizado da criança é um processo que se desenrola a partir da interação infantil com o meio em que vive.

Neste contexto, como uma prática pedagógica presente na interação da criança com o meio em que está inserida, a literatura na educação infantil promove a oportunidade de a criança exercer o direito de desenvolver-se criativa e criticamente. Tem uma função social relevante para a criança, uma vez que permite a inserção dela na sociedade; participa do desenvolvimento do autoconhecimento da criança, como também da construção da criticidade, e esta torna a criança um indivíduo capaz de emitir opinião e tomar conhecimento sobre variados assuntos, além de oportunizar que a criança faça suas próprias escolhas dos textos, livros e outras fontes literárias que se disponha a ler. A prática da literatura nas escolas de educação infantil é aplicada de forma interdisciplinar através da contação de histórias, das brincadeiras, dos desenhos e das manifestações artísticas (Oliveira \& Serighelli, 2020).

A relação da criança com a leitura e a literatura nasce exatamente da prática e da partilha que há no ato de ouvir e contar histórias. Acredita-se então que a prática cotidiana deste instrumento pedagógico na educação infantil, mesmo em uma sociedade contemporânea bastante virtual, contribui para a formação de leitores ativos, crianças que têm prazer em ler e que enxerguem os livros, a leitura e a literatura como algo prazeroso e divertido (Kaercher, 2018).

Mesmo em meio à sociedade virtual, é possível que o professor da educação infantil traga para a sala de aula o prazer pela leitura de livros, utilizando este recurso informacional como "brinquedos", de forma lúdica, através do ouvir, contar e partilhar histórias, do teatro, de pequenas encenações, e até mesmo da execução das práticas lúdicas presentes em livros de atividades infantis. Oliveira e Serighellli (2020), atribuem ao professor, a função de "[...] administrar uma boa capacidade comunicativa através de leituras e didáticas que utilizem os livros com fonte, ponto de partida, assim como a contação de história, teatro, pequenas encenações entre outras metodologias.

Este estudo não tem o objetivo de determinar que os professores apliquem o ouvir e contar histórias todos os dias em sala de aula, mas contribuir teoricamente com o trabalho pedagógico infantil, no que tange a aplicabilidade da literatura como recurso lúdico no processo de desenvolvimento da leitura na educação infantil, bem como na efetiva alfabetização. 


\subsection{Jogos infantis e o brincar}

As crianças, ao brincar, em jogos espontâneos, como por exemplo "esconde-esconde" e "polícia e ladrão", tornam-se capazes de se desenvolver não apenas fisicamente, mas também cognitiva e socialmente, uma vez que segundo Santos (2018, p. 89) "os jogos das crianças são fundamentais para o desenvolvimento de diferentes condutas e também para a aprendizagem de diversos tipos de conhecimentos".

O brincar como recurso lúdico na educação infantil tem sua relevância no processo de construção do conhecimento, no desenvolvimento da linguagem; os jogos proporcionam e facilitam o poder de alcance dos desafios e promovem o desenvolvimento da solidariedade e da partilha dos objetos, jogos e brinquedos (Andrade, 2018). De acordo com Cardoso e Jung (2018), os jogos infantis constituem práticas recreativas usadas para promover interação e entretenimento entre as crianças e os adultos. No ambiente educacional, apresentam-se como aliados nas práticas docentes.

A utilização de jogos infantis como instrumento lúdico na educação infantil permite que o educador traga para a sua prática pedagógica o mundo em que as crianças vivem, pois a motivação, a entrega e o envolvimento das crianças com os jogos vêm do prazer, do divertimento que o brincar propicia a elas. Sendo assim, o jogar e o brincar tornam a aula mais atrativa e satisfatória promovendo comportamentos sociais como cooperação, respeito mútuo e a aceitação do ganhar e perder. As crianças gostam de brincar, necessitam do brincar, portanto a escola deve oferecer espaço e oportunidades de aplicação de jogos infantis e de brincadeiras como recursos de ludicidade (Freitas \& Becker, 2020).

É exatamente por causa do excessivo entusiasmo e dedicação ao brincar, por parte das crianças, que os jogos infantis se constituem primordiais no processo de construção de condutas sociointeracionistas e de absorção de conhecimentos diversos e, portanto, no processo de alfabetização. Oportunizar espaços de jogos na educação infantil é permitir que as crianças vivenciem experiências de criação; manifestem pensamentos, sensações e emoções interagindo com os outros e consigo mesmas (Santos, 2018).

Para Martins, Costa \& Souza (2020), os jogos espontâneos tornam propícia a expansão dos conhecimentos das crianças, por meio do trabalho lúdico na escola. Podem ser aplicados em forma de brincadeiras como faz-de-conta e jogos de construção e montagem; bem como em forma de jogos que possuem regras: jogos didáticos, de tabuleiro, corporais, entre outros. Percebe-se então, que os jogos espontâneos podem apresentar interpretações diversas, porém com suas especificidades e importância no processo educacional.

Pode-se encontrar na literatura, registros explicativos da ordem evolutiva das formas com que os jogos vão se manifestando na vida das crianças de maneira a contribuir com o processo de aprendizagem infantil, desde quando são bebês até os 12 anos de idade. A observação e compreensão do processo evolutivo das manifestações dos jogos infantis na aprendizagem da criança, por parte dos educadores, é importante para promoverem intervenções pedagógicas apropriadas que tratem as crianças como indivíduos criativos e espontâneos.

Enquanto bebês, as atividades lúdicas infantis são ainda limitadas e de baixa exploração devido à baixa capacidade motora, perceptiva e de movimentos. Conforme vão crescendo e desenvolvendo essas e outras novas capacidades, as crianças seguem ampliando o contato com o mundo por meio das vivências sociointeracionistas que modificam o bebê físico e mentalmente. A partir dos 4 meses, a atividade lúdica infantil surge devido ao desenvolvimento motor e da visão possibilitando uma relação do bebê com os objetos, e essa atividade se dá através dos jogos de exercício, inicialmente com ações de agarrar, morder, sacudir, lançar os objetos.

Dentre os jogos de exercício, existem os jogos de manipulação (sensação tátil de materiais diversos como areia, água...) e de construção (noção de cores, formas, ordenação, classificação, equilíbrio, quantidade, peso, tamanho...). A partir da acepção desses tipos de jogos, as crianças passam a ter noção de regras e também é quando surge a simbolização, na seguinte ordem: a criança manipula um objeto - projeta uma imagem mental - e a identifica por meio da linguagem oral. Daí, surgem 
os jogos simbólicos, por meio da aquisição da representação simbólica, conduzida pela imitação e imaginação (SANTOS, 2018).

\subsubsection{Jogos simbólicos}

Dentre os tipos de jogos que podem ser aplicados na prática pedagógica da educação infantil, destacam-se os jogos simbólicos, sendo os de maior significado e mais estudado por Jean Piaget (1978), uma vez que se constituem em brincadeiras que aguçam a criação e imaginação da criança, acontecendo uma relação e integração entre fantasia e realidade (Martins, Costa \& Souza, 2020).

é através do uso da imaginação que a criança representa papéis, comportamentos e situações, bem como compara um elemento dado a um elemento imaginado, e uma imaginação fictícia, visto que essa comparação consiste em uma assimilação deformante. O mesmo autor cita como exemplo de situação, uma criança que deslocar uma caixa, imaginando ser simbolicamente um veículo, identificando que esse veículo "entre o significante e o significado permanece inteiramente subjetivo" (Piaget, 1978, p. 146 apud Martins, Costa \& Souza, 2020).

Se para a literatura, os jogos simbólicos detêm maior significância para o processo de aprendizagem infantil, faz-se necessário um destaque, nesta monografia, para os estudos de Santos (2018), a qual discorreu sobre os jogos simbólicos apresentando uma abordagem evolutiva dos mesmos, baseada nos estudos de Piaget, de 1978. Descreveu as fases e as faixas etárias infantis, ressaltando que não são delimitadas com rigidez, mas que no geral, em cada fase, os jogos simbólicos assumem diferentes características, as quais relacionam-se com as diferentes funções e necessidades infantis.

A abordagem evolutiva dos jogos simbólicos inicia-se desde os meses iniciais de vida, fase em que a criança adquire uma representação simbólica através do ato de imitar algo que já existe. Nesta fase inicial, a criança não tem a capacidade de imaginação, e sim de imitação. Quando mais crescidas, as crianças passam a ter capacidade imaginativa e passam a adquirir uma representação simbólica por meio do ato de imitar algo que não existe, algo imaginado (Santos, 2018). Transfere-se na tabela 2, os registros da abordagem evolutiva dos jogos simbólicos descrita pela autora: 
Tabela 2 - Registros da abordagem evolutiva dos jogos simbólicos.

\begin{tabular}{|c|c|c|c|}
\hline $\begin{array}{c}\text { FAIXA } \\
\text { ETÁRIA }\end{array}$ & $\begin{array}{l}\text { REPRESENTAÇÃO } \\
\text { SIMBÓLICA }\end{array}$ & ATIVIDADES INFANTIS & EXEMPLO \\
\hline \multirow{4}{*}{$\begin{array}{l}1 \text { ano e } \\
\text { meio aos } 3 \\
\text { anos }\end{array}$} & Imitação & $\begin{array}{l}\text { Imitação de si mesmas: } \\
1^{\circ} \text { executa ações fora de seu contexto; } 2^{\circ} \text { executa ações de seu } \\
\text { cotidiano, manipulando bonecos ou bichos de pelúcia. }\end{array}$ & $\begin{array}{l}\text { "Fingir que está dormindo" } \\
\text { ou "comer de mentirinha" }\end{array}$ \\
\hline & Imitação & $\begin{array}{l}\text { Imitação dos adultos: } \\
\text { Observa gestos e ações das pessoas e os reproduz de forma } \\
\text { simplificada; }\end{array}$ & $\begin{array}{l}\text { Imita os gestos e ações dos } \\
\text { pais, dos avós... }\end{array}$ \\
\hline & Imaginação & $\begin{array}{l}\text { Transposição ( } 2 \text { anos de idade): } \\
\text { Utiliza um objeto (real) querendo simbolizar outro objeto } \\
\text { (imaginário) }\end{array}$ & $\begin{array}{l}\text { "Faz-de-conta que o } \\
\text { controle remoto é um } \\
\text { telefone" }\end{array}$ \\
\hline & Imitação e Imaginação & $\begin{array}{l}\text { Jogos de imitação (Entre } 2 \text { e } 3 \text { anos de idade): } \\
\text { Utiliza todo o corpo (assume papéis, vozes, gestos e formas de } \\
\text { locomoção, trazendo seus traços pessoais, comportamento e } \\
\text { personalidade, sem buscar a fidelidade do ser ou objeto } \\
\text { imitado. }\end{array}$ & - \\
\hline \multirow[t]{3}{*}{$\begin{array}{l}3 \text { a } 4 \text { anos } \\
(\text { Faz-de- } \\
\text { conta) }\end{array}$} & Imitação e Imaginação & $\begin{array}{l}\text { Elabora cenas inteiras, quase um teatro. Jogo solitário, criando } \\
\text { monólogos e assumindo diferentes papéis; criação de } \\
\text { personagens imaginários. }\end{array}$ & $\begin{array}{l}\text { Organiza casinhas para as } \\
\text { bonecas, castelos, cidades; } \\
\text { Fala como se fosse } \\
\text { bonecos, alternando os } \\
\text { papéis; } \\
\text { Cria personagens } \\
\text { imaginários e conversa com } \\
\text { eles. }\end{array}$ \\
\hline & Imitação e Imaginação & $\begin{array}{l}\text { Compensação: } \\
\text { Executa no faz-de-conta ações que não consegue realizar no } \\
\text { cotidiano, por não obter porte físico e a idade para realizar } \\
\text { atividades domésticas, por exemplo. }\end{array}$ & $\begin{array}{l}\text { Pega uma roupa de boneca } \\
\text { e faz-de-conta que está } \\
\text { lavando; } \\
\text { Pega um papel e faz-de- } \\
\text { conta que está limpando } \\
\text { um móvel }\end{array}$ \\
\hline & Imitação e Imaginação & $\begin{array}{l}\text { Liquidação: } \\
\text { A criança busca superar situações desagradáveis através da } \\
\text { fantasia }\end{array}$ & $\begin{array}{l}\text { Imita o lobo mau da } \\
\text { história dos três porquinhos } \\
\text { e pede que a passagem que } \\
\text { mais causo medo seja } \\
\text { repetida }\end{array}$ \\
\hline \multirow{2}{*}{$\begin{array}{l}4 \text { a } 7 \text { anos } \\
\text { (intenção de } \\
\text { realismo) }\end{array}$} & Imitação & $\begin{array}{l}\text { Imitação mais próxima da realidade: } \\
\text { Adequa movimentos corporais, expressão vocal e cenários } \\
\text { para os modelos reais. } \\
\text { Forte tendência à ordenação, imitação exata do real e } \\
\text { organização de papéis (surgimento do grupo de jogo) }\end{array}$ & $\begin{array}{l}\text { Cria e reproduz cenas } \\
\text { familiares e de eventos e } \\
\text { dramatiza atividades como } \\
\text { a ida ao médico ou compras } \\
\text { no supermercado }\end{array}$ \\
\hline & Imitação & $\begin{array}{l}\text { Simbolismo coletivo (por volta dos } 7 \text { anos de idade): } \\
\text { Representa cenas mais nitidamente teatrais }\end{array}$ & $\begin{array}{l}\text { Compartilha suas ideias de } \\
\text { criação de cenas com os } \\
\text { adultos e pede ajuda a eles } \\
\text { para suas montagens; } \\
\text { Quer apresentar as cenas a } \\
\text { uma plateia (professor, } \\
\text { colegas...) }\end{array}$ \\
\hline 7 a 12 anos & Jogos de regras & Transição & - \\
\hline
\end{tabular}

Fonte: Adaptado de Santos (2018).

Diante dos registros aqui explanados, percebe-se que a criança, ao experimentar oportunidades de atuar em suas atividades cotidianas, com brincadeiras que envolvem imitação e imaginação estarão mais aptas a desenvolver de forma efetiva sua aprendizagem e também terá facilitado seu processo de alfabetização e leitura, uma vez que este processo estabelece claramente uma relação com os resultados positivos advindos das dinâmicas existentes entre o brincar, o jogar e a leitura de mundo presente nas interações que fazem entre si, com os adultos e com o meio em que vivem. Sendo assim, os jogos simbólicos exercem uma função primordial na vida das crianças contribuindo bastante para o desenvolvimento do 
conhecimento infantil, e por isso, precisam que sejam utilizados como recurso lúdico na educação infantil, nas práticas pedagógicas adotadas pelos professores.

\subsection{Expressões artísticas - o uso de materiais artísticos}

A ludicidade aplicada em sala de aula de educação infantil, através das manifestações artísticas e uso de objetos de arte será explanada neste subitem. Intenta-se discorrer sobre expressões artísticas de forma mais abrangente, além do simples uso do lápis e do papel, pois até um toco de carvão pode riscar um papel como um lápis. Ademais, os materiais de arte merecem ser tratados como recursos de expressão. O importante aqui é redigir sobre a transformação da brincadeira em linguagem artística, conforme o foco principal deste estudo, que é baseado na ludicidade como aliada ao fazer pedagógico e ao desenvolvimento da leitura.

A história da educação infantil no Brasil traz uma concepção, que ainda é atual, sobre as expressões artísticas serem de competência do ensino da disciplina Educação artística, nas escolas (Mangoni, 2019) Contudo, pode-se modificar este olhar, considerando que manifestar-se artisticamente é também se comunicar e partilhar cultura, a qual pode ser utilizada nas mais diferentes formas de arte, inclusive através de movimentos de dança, das práticas musicais, das ações culturais desenvolvidas na escola em sua totalidade, as quais independe do ensino da disciplina educação artística, bem como do nível de ensino.

Entretanto, cabe falar sobre a disciplina de artes nas escolas, considerando que tudo parte primeiramente do ensino da mesma, em que as crianças passam a ter contato com os materiais artísticos e, portanto, a expressar-se através da arte. Ainda assim, a disciplina por si só não é suficiente para cumprir o papel das expressões artísticas de promover o desenvolvimento da aprendizagem infantil, pois ela precisa interagir com as outras disciplinas, conforme Souza (2017, p. 17), "a disciplina de artes não é preenchimento dos espaços vazios, no entanto, ela deve ter uma relação de parceria entre as demais disciplinas".

Com o foco na aprendizagem infantil efetiva, propõe-se que a educação artística é, sobretudo, a promoção da alfabetização do belo, da alfabetização harmoniosa aos olhos de quem vê a arte. É promover o ensino do olhar, do contemplar, assim como se promove o ensino da leitura, da alfabetização. A expressão artística das crianças na educação infantil inicia-se com a manipulação livre de variados tipos de instrumentos e materiais artísticos, a qual promoverá a familiarização das crianças com os recursos disponibilizados pelos professores. Isto porque a criança, com seu evidente interesse e motivação pelo brincar, dá mais importância aos materiais que utiliza no fazer artístico, do que na própria impressão da arte final.

Na Tabela 3 dispõe a prática das expressões artísticas e o uso dos materiais artísticos, compostas por propostas de atuação na educação infantil, de maneira que as atividades pedagógicas não sejam baseadas somente no fazer artístico, mas no preparo das crianças para transformarem o brincar em expressão. 
Tabela 3 - Propostas de condução da ação artística.

\begin{tabular}{|c|c|}
\hline PROPOSTA & CONDUÇÃO \\
\hline $\begin{array}{l}\text { ESPAÇO (respeitar o espaço da criança, fará a criança } \\
\text { respeitar o espaço dos adultos, cuidando para não danificar } \\
\text { móveis e outros espaços. }\end{array}$ & $\begin{array}{l}\text { Além de mesas adequadas para o volume da criança, deve-se explorar } \\
\text { outros espaços como o chão; paredes e painéis para pintura vertical. }\end{array}$ \\
\hline $\begin{array}{l}\text { SUPERFÍCEIS (Antes de receber os instrumentos, a criança } \\
\text { recebe o suporte para não danificar o espaço) }\end{array}$ & $\begin{array}{l}\text { O objeto ou superfície para se trabalhar a arte, chama-se suporte. A criança } \\
\text { precisa diferenciar a superfície do espaço para não pintar, riscar, o derramar } \\
\text { cola sobre as mesas, chão, parede. Ex: papel, tábua, caixa, lixa, balão, tela... } \\
\text { "O suporte é colocado no espaço de trabalho, no lugar da criança, à sua } \\
\text { frente". }\end{array}$ \\
\hline $\begin{array}{l}\text { INSTRUMENTOS (Ferramentas para aplicação dos } \\
\text { produtos de arte) }\end{array}$ & $\begin{array}{l}\text { São as ferramentas (lápis, pincel, caneta, bastões para argila, tesouras, } \\
\text { carimbos, serrilhas, martelo, alicate, gravetos, pauzinhos para riscar } \\
\text { superfícies, penas para molhar em pigmentos, canudos... Os instrumentos } \\
\text { naturais e primitivos são os dedos, seguidos das mãos. }\end{array}$ \\
\hline MASSAS E SUBSTÂNCIAS & $\begin{array}{l}\text { Materiais que envolvem toda a atividade artística (água, terra, argila, tinta, } \\
\text { massa de modelar, areia, cola, algodão, giz de cera, farinha, corante, brilho, } \\
\text { purpurina, papel celofane... }\end{array}$ \\
\hline $\begin{array}{l}\text { ELEMENTOS DE APLICAÇÃO (Outros materiais que a } \\
\text { imaginação permitir utilizar, desde que não acarrete em } \\
\text { perigo de manuseio) }\end{array}$ & $\begin{array}{l}\text { Elementos colados, costurados, pregados, espetados ou agregados a } \\
\text { superfícies para trabalhos bidimensionais e tridimensionais (botões, palitos, } \\
\text { grãos, fios de lã, barbantes, tampinhas, lantejoulas...) }\end{array}$ \\
\hline
\end{tabular}

Fonte: Adaptada de Gomes (2018).

Observa-se na Tabela 2 que a condução da ação artística para uma superfície realiza-se através do uso das mãos, dos dedos ao manusear substâncias e que faz a criança lambuzar, sujar, riscar, imprimir suas marcas. Assim é possível desenvolver sua escrita sobre as propostas de espaço, superfícies, instrumentos, elementos de aplicação adequados à ação artística infantil.

\subsection{Práticas musicais}

A música tem valor de recurso lúdico que pode contribuir com o processo de desenvolvimento da aprendizagem. Entretanto, não se propõe a utilização do recurso musical somente como instrumento de ensino, mas também como uma brincadeira, com a ideia do brincar enquanto atividades de construção da identidade infantil, ou seja, dando a oportunidade de a criança expressar-se, tornar-se indivíduo participante do mundo e parte de um grupo social. Além disso, não se tem a pretensão de propor as práticas musicais na educação infantil como ferramentas para a formação de músicos ou professores de música, e sim como recurso lúdico utilizado para promover a compreensão da linguagem musical no universo infantil, de como ela possibilita a manifestação de sensações e emoções dos indivíduos em formação.

A linguagem musical é presente na vida dos seres humanos desde a vida intrauterina, quando provocados pelos sons corporais da mãe como batimento cardíaco, o fluxo do sangue, respiração, movimentação dos órgãos excretores e principalmente a voz da mãe, que a ciência diz constituir material sonoro referencial para os bebês antes do nascimento (Kastein \& Pacífico, 2018).

Quando já inseridas no mundo, pós-nascimento, as crianças experimentam outros tipos de sons e ritmos. Dentre eles, o principal e mais agradável às crianças a partir de 1 ano e meio, é o som ambiental, os sons da natureza, dos animais, o canto dos pássaros, os ruídos das folhas balançando, do vento, dos passos de uma pessoa se aproximando. Esse composto sonoro permite que as crianças adquiram referenciais auditivos que as fazem ter a noção do tempo e do espaço em que estiverem e, portanto, possam observar a natureza. Sobre o trabalho com os sons da natureza na educação infantil. O professor pode desenvolver atividades de percepção dos sons ambientais, promovendo a orientação das crianças quanto ao período do dia e local em que estão e ainda fazendo um registro do que elas escutam no caminho de casa para a escola (Maffioletti, 2018). 
Research, Society and Development, v. 11, n. 1, e52011125228, 2022

(CC BY 4.0) | ISSN 2525-3409 | DOI: http://dx.doi.org/10.33448/rsd-v11i1.25228

Ao ter contato com outros compostos sonoros, as crianças passam a utilizar e reproduzir os instrumentos expressivos de sua cultura. A interação com diversos sons e ruídos permite novas descobertas e a expressão de sensações e emoções diferentes, tanto através de sons que animam (brinquedos sonoros, por exemplo) quanto de sons que irritam (sirenes, barulho de suspense e terror, por exemplo) as crianças. Os novos recursos sonoros que promovem sons e ruídos sensíveis às crianças são os advindos da televisão e da convivência com seus pais, familiares e outros (Kastein \& Pacífico, 2018).

Pensando no processo educacional infantil e na atuação das práticas musicais como recurso lúdico, consideremos a música como instrumento que facilita e possibilita tal processo, de forma que promove o desenvolvimento das características humanas físicas, mentais, sociais, emocionais e espirituais.

A educação musical nas escolas deve estar conectada ao processo criativo (fazer musical) e ao desenvolvimento da escrita (escrita musical). Menezes (2019) aponta benefícios da música para os aspectos humanos físico, psíquico, cognitivo/mental e educacional. Cabe ressaltar que os sons perceptíveis pela criança permitem a aquisição de referenciais auditivos que propicia a noção do tempo e do espaço em que a criança está. Além disso, exerce estímulo para a ativação da memória e cognição e desenvolve as habilidades lógico-matemáticas e linguísticas.

Nesse contexto e partindo de toda ideia de ludicidade aqui presente, traz-se a música como instrumento de aprendizagem e que promove o aprender com prazer, tornando o espaço da sala de aula agradável e favorável ao desenvolvimento infantil. Kastein e Pacífico (2018) citam a experiência musical como fator que enriquece o aprendizado, ajudando o desenvolvimento da expressão, equilíbrio, autoestima e autoconhecimento.

\section{Considerações Finais}

O estudo revelou, através da revisão de literatura, que a temática sobre alfabetização, letramento, leitura, ludicidade e prática pedagógica, é bastante relevante e repercutida no meio acadêmico e vem sendo fortemente discutida ao longo da história da educação infantil. Com interesse em se aprofundar e produzir mais referencial teórico acerca dos assuntos; bem como dar ênfase ao uso da ludicidade no processo de desenvolvimento da aprendizagem infantil e da leitura, buscou-se alcançar o objetivo de compreender a importância da ludicidade na aquisição da leitura e escrita, bem como apresentar os meios lúdicos como instrumentos de aprendizagem nos anos iniciais, descrevendo os benefícios que cada atividade pode proporcionar para os alunos da educação infantil.

No contexto da educação infantil, pode-se constatar que é indispensável a compreensão de que o professor como mediador do conhecimento e autônomo no desenvolvimento de suas práticas pedagógicas, deve ter a criança como indivíduo que possui suas particularidades diferenciadas dos adultos no que diz respeito à forma de se comunicar, ser, agir e sentir, ou seja, de manifestar-se no mundo. Com esta concepção sobre os alunos, o educador tem condições de promover práticas pedagógicas que promovam experiências significativas com as múltiplas linguagens expandindo as habilidades de expressões das crianças.

No trabalho educacional com crianças, visando a ampliação das oportunidades de aprendizagem, é essencial despertar nelas a motivação pela leitura, através de diversos fatores como a sensibilidade, a curiosidade, a criatividade e a criticidade, e não apenas considerar a leitura como uma simples atividade escolar. No alcance desse conjunto de fatores, as crianças desenvolvem-se e aprendem com mais eficiência e com maior consciência de si e do meio em que vivem. Sendo assim, tem-se a ludicidade como uma aliada no processo, visto que em toda literatura estudada constatou-se o benefício de sua aplicação nas práticas educacionais.

É a ludicidade que traz para a sala de aula, estratégias lúdicas de leitura, e inusitadas e variadas descobertas, por meio dos instrumentos aqui explanados: literatura, jogos e brincadeiras, arte e música. Vale ressaltar que o desenvolvimento das 
estratégias de leitura deve ter a intenção de aplicar a leitura de forma prazerosa, como uma prática além de educacional, social, para a formação do indivíduo como sujeito crítico.

Sugere-se então, que novos estudos como este sejam realizados por pesquisadores a fim de trazer novas perspectivas a respeito da educação infantil e do papel da ludicidade para a pedagogia. Que sejam trazidos para a literatura, novos paradigmas, novas propostas de aplicação dos instrumentos lúdicos na sala de aula, isso tudo a partir de pesquisas atuais, contemplando ideias e práticas recentes.

\section{Agradecimentos}

A Universidade Paulista - UNIP, Recife/Pernambuco; à Coordenação de Aperfeiçoamento de Pessoal de Nível Superior - CAPES.

\section{Referências}

Andrade, L. R. D. (2018). A importância do lúdico na educação infantil: um estudo de caso em uma creche pública. 2018 . Trabalho de Conclusão de Curso (Licenciatura em Pedagogia). Centro de Educação da Universidade Federal da Paraíba, João Pessoa, 2018. https://repositorio.ufpb.br/jspui/bitstream/123456789/14099/1/LRA07022019.pdf

Azevedo, R. N. C. (2017). O lúdico contribuindo na formação de professores da educação infantil e dos anos iniciais do ensino fundamental. Revista Amazônica de Ensino de Ciências, v. 2, n. 3, p. 84-94, 2017.

Brasil. (2016). Base Nacional Comum Curricular. Proposta preliminar. Segunda versão revista. Brasília: MEC, 2016. http://basenacionalcomum.mec.gov.br/>. Acesso em: 07 out. 2021.

Brasil. (2017). Base Nacional Comum Curricular. Brasília, DF, 2017. http://basenacionalcomum.mec.gov.br/

Brasil. Resolução CEB/CNE $\mathrm{n}^{\mathrm{o}} 5$ de 17/12/2009. Fixa as Diretrizes Curriculares Nacionais para a Educação Infantil. https://www.legisweb.com.br/legislacao/?id=112015.

Bujes, M. I. E. (2018). Escola Infantil: pra que te quero? In: Educação Infantil: pra que te quero? São Paulo: Artmed, 2018. cap. 1

Camargo, G., Cardoso, M. V. M., Monteiro, F. (2018). A escrita e a leitura na educação infantil: uma perspectiva de letramento. Revista Linguagem, Ensino e Educação-Lendu, 4(1). http://periodicos.unesc.net/lendu/article/download/2607/2447.

Cardoso, J.I.W.; Jung, H.S. (2018). O lúdico na educação infantil: aprendizagem e diversão. In: Semana Científica da Unilasalle (SEFIC), 2018, Canoas. Anais do SEFIC 2018 [...]. https://anais.unilasalle.edu.br/index.php/sefic2018/article/view/1064/1007.

Cartaxo, S. R. M., Fontana, M., \& Smaiotto, G. (2020). As facetas da alfabetização nos cursos de Pedagogia: desafios para a formação do professor. Currículo Sem Fronteiras, 20, 1126-1147. http://dx.doi.org/10.35786/1645-1384.v20.n3.25.

Celestino, P. G. (2019). A oralidade infantil e desenvolvimento cognitivo a partir da prática docente. Revista Internacional de apoyo a la inclusión, logopedia, sociedad y multiculturalidad, 5(1), 51-67. https://www.redalyc.org/journal/5746/574660909004/html/.

Ciríaco, F. L. (2020). A leitura e a escrita no professo de alfabetização. Revista Educação Pública, 20(4). https://educacaopublica.cecierj.edu.br/artigos/20/4/aleitura-e-a-escrita-no-processo-de-alfabetizacao.

Dornelles, L. V. (2018). Na escola infantil todo mundo brinca se você brinca. In: Educação Infantil: pra que te quero? São Paulo: Artmed, 2018. cap. 9.

Felipe, J. (2018). Desenvolvimento infantil na perspectiva sociointeracionista: Piaget, Vygotsky, Wallon. In: Educação Infantil: pra que te quero? São Paulo: Artmed, 2018. cap. 3.

Fontana, F. (2018). Técnicas de pesquisa. In: T. Mazucato (org.). Metodologia da pesquisa e do trabalho científico. FUNEPE.

Freire, P. (1989). A importância do ato de ler: em três artigos que se completam. São Paulo: Cortez, 1989. (Coleção polêmicas do nosso tempo; 4). https://educacaointegral.org.br/wp-content/uploads/2014/10/importancia_ato_ler.pdf.

Freitas. S. D. A. \& Becker, T. M. (2020). A importância do lúdico e o papel do professor na Educação infantil: uma revisão bibliográfica em Periódicos nacionais. $\quad$ In: VII Congresso CONED. https://editorarealize.com.br/editora/anais/conedu/2020/TRABALHO_EV140_MD1_SA_ID5369_04092020160240.pdf.

Garcia, G.A. (2019). O lúdico da matemática na educação infantil. In: Santos, C.H.M. (org). Novas perspectivas em educação. São Paulo: Editora WI, 2019. p. 42-63.

Gomes, P. M. B. (2018). Os materiais artísticos na educação infantil. In: Educação Infantil: pra que te quero? São Paulo: Artmed, 2018. cap. 10.

Granados, A. I. M. L. (2020). A leitura e a formação do leitor no âmbito da biblioteca escolar: um mapeamento nos anais do CONEDU entre 2014 a 2019. 2020. https://editorarealize.com.br/editora/anais/conedu/2020/TRABALHO_EV140_MD1_SA8_ID6033_31082020074608.pdf. 
Research, Society and Development, v. 11, n. 1, e52011125228, 2022

(CC BY 4.0) | ISSN 2525-3409 | DOI: http://dx.doi.org/10.33448/rsd-v11i1.25228

Junqueira, F. G. D. A. (2018). Conversando, lendo e escrevendo com as crianças na educação infantil. In: Educação Infantil: pra que te quero? São Paulo: Artmed, 2018. cap. 12.

Kaercher, G. E. (2018). E por falar em Literatura... In: Educação Infantil: pra que te quero? São Paulo: Artmed, 2018. cap. 7.

Kastein, V. R. B., \& Pacífico, M. (2018). A formação musical na educação infantil: a questão docente e as possibilidades da musicalização. Revista Profissão Docente, 18(38), 143-157. https://revistas.uniube.br/index.php/rpd/article/view/1196

Lima, D. J. Casagrande, S. (2020). Alfabetização e letramento na educação infantil. Saberes Pedagógicos, Criciúma, 4(3), set./dez. http://periodicos.unesc.net/pedag/article/view/6200.

Maffioletti, L. D. A. (2018). Práticas musicais na escola infantil. In: Educação Infantil: pra que te quero? São Paulo: Artmed, 2018. cap. 11.

Mangoni, M. (2019). A expressão artística: uma compreensão que vai além do lápis e do papel. 15 f. Artigo de conclusão de curso (Licenciatura em Pedagogia). Universidade de Passo Fundo, Passo Fundo, RS, 2019. http://repositorio.upf.br/handle/riupf/1826.

Martins, M. H.; Costa, T. C. D. O.; Souza, K. C. R. D. (2020). A importância dos jogos e das brincadeiras na Educação Infantil. Revista Científica Multidisciplinar Núcleo do Conhecimento, ano 05, 18(11), 101-114. https://www.nucleodoconhecimento.com.br/educacao/a-importancia.

Mazo, A., Oliveira, R. K. D., \& Tomazzoni, E. L. (2021). Análisis bibliográfica y sistemática de la literatura académica de los términos "ciudades inteligentes", "turismo" y “competitividad". Turismo: Visão e Ação, 23(1), 148-168. https://doi.org/10.14210/rtva.v23n1.p148-168

Menezes, A. H. N., Duarte, F. R., Carvalho, L. O. R., \& Souza, T. E. S. (2019). Metodologia científica: teoria e aplicação na educação a distância. Universidade Federal do Vale do São Francisco, Petrolina-PE. e-book, 83p.

Menezes, L. D. F. V. (2019). A música e o desenvolvimento da criança da educação infantil. Trabalho de Conclusão de Curso (Pós-graduação em Docência na Educação Básica). Universidade Federal de Minas Gerais, Belo Horizonte. https://repositorio.ufmg.br/bitstream/1843/34879/1/LETICIA.pdf.

Miranda, D. A. (2018). Motricidade humana e percepção sensorial Em crianças até 2 anos de idade. Trabalho de Conclusão de Curso (Graduação em

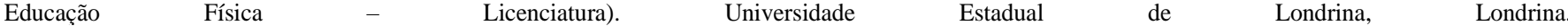
http://www.uel.br/cefe/demh/portal/pages/arquivos/TCC/2017/Debora\%20Alvez\%20Miranda.pdf.

Serighelli, M. A., \& OLIVEIRA, L. C. (2020). A literatura infantil enquanto estratégia pedagógica no processo de formação cidadã com alunos da educação básica. Anuário Pesquisa E Extensão Unoesc Videira, 5, e23706-e23706. https://unoesc.emnuvens.com.br/apeuv/article/download/23706/14036/.

Oliveira, Z. D. M. R. D. (2020). Educação Infantil. 8. ed. São Paulo: Cortez, 2020.

Pattuzzo, Y. G., Gonçalves, É. D. S. (2019). As múltiplas linguagens na Educação Infantil. Revista Científica Multidisciplinar Núcleo do Conhecimento. Ano 04, 1(8), pp. 53- 71. ago. 2019. https://www.nucleodoconhecimento.com.br/educacao/multiplas-linguagens.

Pereira, A. S. et al. (2018). Metodologia da pesquisa científica. UFSM. https://repositorio. ufsm. br/bitstream/handle/1/15824/Lic_Computacao_MetodologiaPesquisa-Cientifica. pdf.

Rocha, P.S.V.S. (2017). A importância do lúdico na educação infantil: uma análise a partir da concepção de professores. $2017.31 \mathrm{f}$. Trabalho de Conclusão de Curso (Licenciatura em Pedagogia). Universidade Federal da Paraíba, Centro de Educação, Alagoa Grande. https://repositorio.ufpb.br/jspui/bitstream/123456789/4085/1/PSVSR14032018.pdf.

Saccomani, M. C. D. S. (2018). A importância da educação pré-escolar para o desenvolvimento da linguagem oral e escrita: contribuições à luz da pedagogia histórico-crítica e da psicologia histórico-cultural. Tese (Doutorado em Educação Escolar). Faculdade de Ciências e Letras - Unesp/Araraquara. http://www.uel.br/cefe/demh/portal/pages/arquivos/TCC/2017/Debora\%20Alvez\%20Miranda.pdf.

Santos, V. L. B. D. (2018). Promovendo o desenvolvimento do faz-de-conta na Educação Infantil. In: Educação Infantil: pra que te quero? São Paulo: Artmed, 2018. cap. 8 .

Silva, C.M.P. (2019). O lúdico na educação infantil: aspectos presentes na prática docente. 2019. 20 f. Trabalho de Conclusão de Curso (Licenciatura em Pedagogia). Unidade Acadêmica de Garanhuns, Universidade Federal Rural de Pernambuco, Garanhuns. https://repository.ufrpe.br/bitstream/123456789/1037/1/tcc_art_carlenemichelypereirasilva.pdf.

Souza, F. P. D. (2017). A importância da disciplina de artes na educação: capacidade e criatividade das crianças. Trabalho de Conclusão de Curso (Graduação em Educação do Campo - Licenciatura). Universidade de Brasília, Planaltina, DF. https://bdm.unb.br/bitstream/10483/19586/1/2017_FernandaPatriciadeSouza.pdf.

Souza, M.N.J.; Juvêncio, J.S. \& Moreira, M.A. (2019). Jogos e brincadeiras: o lúdico na educação infantil. In: VI Congresso Nacional de Educação CONEDU, 6, 2019, Fortaleza. Anais do VI CONEDU [...]. 